\title{
Glosa do wyroku Naczelnego Sądu Administracyjnego z dnia 14 kwietnia 2015 r., sygn. I FSK 1493/14
}

Teza: Ewentualny, uboczny wpływ dokonywanych prac na środowisko morskie nie może decydować o możliwości zastosowania stawki określonej w art. 83 ust. 1 pkt 11 ustawy o VAT.

\section{Stan faktyczny i prawny}

Naczelny Sąd Administracyjny (NSA) wyrokiem z dnia 14 kwietnia 2015 r., sygn. I FSK 1493/14, po rozpoznaniu skargi kasacyjnej Ministra Finansów od wyroku Wojewódzkiego Sądu Administracyjnego (WSA) w Warszawie z dnia 1 kwietnia 2014 r., sygn. III SA/Wa 2842/13 w przedmiocie interpretacji indywidualnej Ministra Finansów z dnia 9 lipca 2013 r., uchylił zaskarżony wyrok oraz oddalił skargę.

Powyższy wyrok dotyczył następującego stanu faktycznego. Spółka S. GmbH z siedzibą w Niemczech wystąpiła do ministra finansów o wydanie indywidualnej interpretacji w sprawie stawki podatku od towarów i usług dotyczącej budowy elementów systemu ochrony brzegu morskiego Morza Bałtyckiego ${ }^{1}$. Zakres usług miał obejmować: modernizację i odbudowę ostróg brzegowych standardowo o średniej długości ok. $110 \mathrm{~m}$ i rozstawie ok. 60 do $110 \mathrm{~m}$; budowę progów podwodnych równolegle do linii brzegowej na płytkim przybrzeżu w odległości

${ }^{1}$ Ustalenia dokonane na podstawie wyroku WSA w Warszawie z 1 IV 2014 r., sygn. III SA/Wa 2842/13, http://orzeczenia.nsa.gov.pl (dostęp: 12 VII 2015). 
120-150 m od linii brzegu; sztucznego zasilania (refulacja) w piasek średnioziarnisty o granulacji zbliżonej do osadów macierzystych strefy brzegowej rejonu, na obszarze obejmującym brzegi oraz pas przybrzeża między linią brzegową a linią wzdłuż brzegowych progów podwodnych. Wymienione prace miały być wykonywane na podstawie umów zawieranych $\mathrm{z}$ właściwym terytorialnie Urzędem Morskim w ramach realizacji projektów objętych Ustawą z dnia 28 marca 2003 r. o ustanowieniu programu wieloletniego "Program ochrony brzegów morskich"2.

Spółka S. we wniosku o interpretację uznała, że opisane prace należy kwalifikować jako usługi związane z ochroną środowiska morskiego, do rozliczeń których ma zastosowanie art. 83 ust. 1 pkt 11 Ustawy z dnia 11 marca 2004 r. o podatku od towarów i usług 3 . Wskazała również, że ze względu na brak legalnej definicji ochrony środowiska w ustawie o VAT konieczne jest odwołanie się do definicji uregulowanej w Ustawie z dnia 27 kwietnia $2001 \mathrm{r}$. Prawo ochrony środowiska ${ }^{4}$, zgodnie z którą przez ochronę środowiska należy "rozumieć działanie bądź zaniechanie, umożliwiające zachowanie lub przywracanie równowagi przyrodniczej, w tym racjonalne kształtowanie środowiska zgodnie z zasadą zrównoważonego rozwoju". Wobec takiej treści art. 3 pkt 39 p.o.ś. Spółka S. stanęła na stanowisku, że racjonalne kształtowanie środowiska morskiego obejmuje również zapewnienie stabilizacji brzegu morskiego i zapobieganie zanikowi plaż w celu zapewnienia równowagi biologicznej oraz zrównoważonego rozwoju.

W ocenie Spółki S. w sprawie powinien mieć zastosowanie także art. 15 Konwencji sporządzonej w Helsinkach z dnia 9 kwietnia 1992 r. o ochronie środowiska morskiego obszaru Morza Bałtyckiego ${ }^{5}$, który formułuje potrzebę zachowania różnorodności biologicznej i ochrony procesów ekologicznych w granicach Morza Bałtyckiego i przybrzeżnych ekosystemów.

$\mathrm{W}$ interpretacji indywidualnej z dnia 9 lipca 2013 r. minister finansów uznał stanowisko Spółki S. za nieprawidłowe, argumentując tym, że aby zastosować obniżoną $0 \%$ stawkę podatku do usług związanych z ochroną środowiska morskiego na podstawie art. 83 ust. 1 pkt 11 ustawy o VAT, łącznie spełnione muszą być: kryterium rodzaju usług (usługi muszą być związane z ochroną tego środowiska) oraz kryterium

\footnotetext{
${ }^{2}$ Dz.U. Nr 67, poz. 621, dalej „ustawa o programie ochrony brzegów morskich”.

${ }^{3}$ Dz.U. 2011 Nr 177, poz. 1054 ze zm., dalej „ustawa o VAT".

${ }^{4}$ Dz.U. 2008 Nr 25, poz. 150 ze zm., dalej „p.o.ś.".

${ }^{5}$ Dz.U. 2000 Nr 28, poz. 346, dalej „Konwencja helsińska”.
} 
ekosystemu (usługi muszą dotyczyć środowiska morskiego). Zdaniem organu podatkowego usługi wykonywane w celu ochrony brzegu morskiego mogą korzystać z opodatkowania stawką podatku $0 \%$ wyłącznie w przypadku, gdy są jednocześnie związane nie tyle ze środowiskiem morskim, co z jego ochroną.

Organ podatkowy, odwołując się do definicji słownikowej pojęcia "ochrona środowiska”, stwierdził, że "ochrona” oznacza „zabezpieczenie, opiekę, osłonę przed zanieczyszczeniem, szkoda, skrzywdzeniem, niebezpieczeństwem" ${ }^{\prime \prime}$, i na tej podstawie uznał, że wykonywane przez Spółkę S. usługi będa, co prawda, miały związek ze środowiskiem morskim, jednak nie będą odnosiły się do jego ochrony, albowiem nie będą związane z ochroną środowiska morskiego przed mającymi na nie wpływ czynnikami innymi niż przyrodnicze, a więc wynikającymi z działalności człowieka, industrializacji, rozwoju transportu morskiego, nadmiernego rybołówstwa itp. Organ dokonujący interpretacji podkreślił, że oddziaływanie mórz na ląd jest procesem naturalnym, niezależnym od człowieka, a ewentualne działania skierowane na ochronę brzegów morskich służą interesom samego człowieka, a nie środowiska morskiego, które w wyniku ruchu wody i związanego z tym podmywania lądu nie doznaje żadnej szkody, której - w ocenie organu - należałoby zapobiegać z punktu widzenia środowiska morskiego. Analiza charakteru prac, które zamierza wykonać Spółka S., prowadziła wobec powyższego do wniosku, że będą one wykonywane w celu ochrony środowiska lądowego, a konkretnie służyć będą zachowaniu w stanie niepogorszonym już istniejących brzegów morskich i ich zabezpieczeniu przed dalszym zniszczeniem.

Na powyższą interpretację spółka wniosła skargę do WSA w Warszawie, który wyrokiem z 1 kwietnia 2014 r. uznał skargę za zasadną. W ocenie tego sądu w sprawie miały zastosowanie przepisy: Dyrektywy Parlamentu Europejskiego i Rady 2008/56/WE z dnia 17 czerwca 2008 r. ustanawiającej ramy działań Wspólnoty w dziedzinie polityki środowiska morskiego (dyrektywa ramowa w sprawie strategii morskiej $)^{7}$, Konwencji helsińskiej oraz p.o.ś. Sąd uznał, że pod pojęciem ochrony środowiska morskiego rozumieć należy działania mające na celu chronienie, zachowanie i odnowienie środowiska morskiego w sposób zapewniający utrzymanie jego różnorodności biologicznej oraz

\footnotetext{
${ }^{6}$ Hasło „Ochrona”, Słownik jezzyka polskiego PWN, http://sjp.pwn.pl/szukaj/ochrona. html (dostęp: 10 IX 2015).

7 Dz.Urz. UE L 164/19 z 25 VI 2008 r., dalej „Dyrektywa 2008/56/WE”.
} 
zachowanie jego zróżnicowanego i dynamicznego charakteru, w tym również ochronę tego środowiska przed zanieczyszczeniami. Przyjmując takie rozumienie ochrony środowiska morskiego, WSA wskazał, że definicja zawarta w interpretacji ministra finansów ma charakter zawężający, ogranicza bowiem pojęcie ochrony środowiska morskiego tylko i wyłącznie do czynności mających na celu przeciwdziałanie negatywnym skutkom działalności człowieka. Tymczasem pojęcie ochrony środowiska morskiego obejmuje nie tylko zapobieganie jego zanieczyszczeniom i ich skutkom, ale również działalność mającą na celu jego chronienie, zachowanie i odnowienie w sposób zapewniający utrzymanie jego różnorodności.

Sąd administracyjny z jednej strony podzielił stanowisko ministra finansów, zgodnie z którym ochrona brzegu morskiego przed jego dalszą erozją nie może być utożsamiona z ochroną środowiska morskiego. Jednak, opierając się na informacjach przedstawionych przez Spółkę S., uznał, że realizowane przez nią czynności będą miały wpływ na poprawę jakości wód przybrzeżnych, tj. będą powodowały powstawanie warunków do rewitalizacji i zwiększenia bioróżnorodności strefy bliskiego przybrzeża południowego Bałtyku, wykonywane zaś budowle będą mogły stanowić schronienie i miejsce żerowania wielu gatunków ryb. Tym samym uznał, że usługi świadczone przez Spółkę S. są związane z ochroną środowiska morskiego w rozumieniu art. 83 ust. 1 pkt 11 ustawy o VAT.

Minister finansów zaskarżył powyższy wyrok w całości, zarzucając sądowi I instancji naruszenie prawa materialnego, tj. art. 83 ust. 1 pkt 11 ustawy o VAT, poprzez błędną jego wykładnię i błędne zastosowanie polegające na uznaniu, że opisane przez skarżącą spółkę prace związane $z$ budową elementów systemu ochrony brzegów Morza Bałtyckiego w ramach programu wieloletniego "Program ochrony brzegów morskich" będą usługą związaną $\mathrm{z}$ ochroną środowiska morskiego $\mathrm{w}$ rozumieniu art. 83 ust. 1 pkt 11 ustawy o VAT.

Naczelny Sąd Administracyjny, rozpatrując skargę kasacyjna, stwierdził, że przy określaniu zakresu możliwości stosowania odpowiedniej stawki podatkowej, o której mowa w art. 83 ust. 1 pkt 11 ustawy o VAT, nie sposób pominąć celu, w którym wykonywane są konkretne usługi. NSA zwrócił też uwagę, że przepisy powoływane przez sąd I instancji nie pozwalają wprawdzie na ustalenie jednoznacznej definicji pojęcia "środowiska morskiego", jednak pogląd zaprezentowany w zaskarżonym wyroku jest błędny, albowiem zasadniczy cel określony w art. 83 ust. 1 pkt 11 ustawy o VAT musi być związany ze środowiskiem morskim. Cel 
taki nie może zostać osiągnięty jedynie pobocznie, przy realizacji innego celu niezwiązanego bezpośrednio z tym środowiskiem. W ocenie NSA program ochrony brzegów morskich ma realizować przede wszystkim cel ekonomiczny, a dopiero w dalszej kolejności ochronę środowiska strefy brzegowej. Zatem z założenia program ochrony brzegów morskich ma chronić brzegi morskie, a nie środowisko morskie. Analiza charakteru prac, które zamierza wykonać Spółka S., prowadzi do wniosku, że będą one służyć zachowaniu w stanie niepogorszonym już istniejących brzegów morskich i ich zabezpieczeniu przed dalszym zniszczeniem.

Wobec powyższego NSA, uwzględniając skargę, uznał, że ewentualne działania skierowane na ochronę brzegów morskich służą interesom samego człowieka, a nie środowiska morskiego, które w wyniku ruchu wody i związanego z tym podmywania lądu nie doznaje żadnej szkody, której należałoby zapobiegać z punktu widzenia środowiska morskiego.

\section{Ocena wyroku NSA}

Zgodnie z art. 188 Ustawy z dnia 30 sierpnia 2002 r. Prawo o postępowaniu przed sądami administracyjnymi ${ }^{8} \mathrm{w}$ brzmieniu obowiązującym w dniu wydania komentowanego wyroku NSA mógł uchylić zaskarżone orzeczenie i rozpoznać skargę, jeżeli nie było naruszeń przepisów postępowania, które mogły mieć istotny wpływ na wynik sprawy, a zachodziło jedynie naruszenie prawa materialnego. W takim przypadku NSA orzeka na podstawie stanu faktycznego przyjętego w zaskarżonym wyroku ${ }^{9}$. W orzecznictwie przyjmuje się, że „dostateczne wyjaśnienie sprawy to stan zdolności do wydania wyroku"10, a jak podnosi się w literaturze, "kategoryczne stwierdzenia ustawodawcy typu "nie ma” $\mathrm{i}$ "zachodzi” świadczą, iż miał on na myśli stan istniejący obiektywnie, a nie treść zarzutów podnoszonych przez stronę ${ }^{\prime \prime 1}$. W doktrynie stwierdza się

${ }^{8}$ Tekst jedn. Dz.U. 2012, poz. 270 ze zm., dalej „p.p.s.a.”.

${ }^{9} \mathrm{Na}$ temat nowelizacji art. 188 zob.: R. Hauser, W. Piątek, A. Skoczylas, Środki odwoławcze w postępowaniu sadowoadministracyjnym w świetle ustawy nowelizującej z dnia 9 kwietnia 2015 r. - analiza najistotniejszych zmian, "Zeszyty Naukowe Sądownictwa Administracyjnego" 2015, nr 4, s. 9; W. Ryms, Co kryje się pod pojęciem dostatecznego wyjaśnienia istoty sprawy, "Rzeczpospolita” 5 I 2016.

${ }^{10}$ Wyrok NSA z 3 VII 2012 r., sygn. II GSK 2058/11, http://orzeczenia.nsa.gov.pl (dostęp: 12 VIII 2015).

${ }^{11}$ B. Dauter, B. Gruszczyński, Komentarz do art. 188 ustawy - Prawo o postępowaniu przed sq̨dami administracyjnymi, LEX (dostęp: 12 VIII 2015). 
ponadto, że dostateczne wyjaśnienie sprawy pozwala na wydanie wyroku reformatoryjnego, jeżeli nie ma wątpliwości co do stanu faktycznego oraz stanu prawnego ${ }^{12}$. Jest to okoliczność mająca istotne znaczenie, albowiem w sprawach, w których podejmowane jest orzeczenie kasacyjne, podważenie przez skarżącego braku dostatecznego wyjaśnienia sprawy nie jest równoznaczne z podważeniem "stanu zdolności do wydania wyroku" $^{\prime \prime}$. Faktem jest, że sądy administracyjne co do zasady nie prowadzą postępowania dowodowego i nie ustalają stanu faktycznego sprawy, ale dokonują oceny legalności działań organów administracji w tym zakresie, jednak w przypadku zastosowania art. 188 p.p.s.a. konieczne jest uznanie przez sąd, że sprawa została dostatecznie wyjaśniona oraz że zachodzi zdolność do wydania wyroku. Należy zwrócić uwagę na okoliczność, że orzeczenie NSA wydane zostało wskutek rozpoznania skargi kasacyjnej od wyroku sądu I instancji dotyczącej interpretacji podatkowej. Ma to o tyle istotne znaczenie, iż „specyfika postępowania $\mathrm{w}$ przedmiocie interpretacji indywidualnej polega między innymi na tym, że "organ wydający interpretację porusza się niejako tylko i wyłącznie $\mathrm{w}$ ramach stanu faktycznego przedstawionego przez wnioskodawcę oraz wyrażonej przez niego oceny prawnej (stanowiska)"14. W sprawach dotyczących interpretacji nie jest prowadzone postępowanie dowodowe, a obowiązkiem wyczerpującego przedstawienia stanu faktycznego ustawodawca obciążył wnioskodawcę ${ }^{15}$. Organ wydający interpretację zobowiązany jest do analizy okoliczności podanych we wniosku i wydania na ich podstawie własnego stanowiska, które jest ustosunkowaniem się do poglądu (stanowiska) prezentowanego przez wnioskodawcę. Powyższe oznacza, że organ podatkowy dokonuje oceny, czy interpretacja przepisów prawa przedstawiona przez podatnika jest prawidłowa, uwzględniając konkretny, zaprezentowany we wniosku stan faktyczny ${ }^{16}$.

${ }^{12}$ P. Pietrasz, Reformatoryjne orzekanie przez wojewódzkie sądy administracyjne w przypadku sadowej kontroli decyzji i postanowień - uwagi de lege ferenda, w: Z zagadnień prawa rolnego, cywilnego i samorządu terytorialnego. Księga Jubileuszowa Profesora Stanisława Prutisa, pod red. J. Bieluka i in., Białystok 2012, s. 815.

${ }^{13}$ Wyrok NSA z 19 XI 2015 r., sygn. II FSK 2624/13, www.orzeczenia.nsa.gov.pl (dostęp: 3 II 2016).

${ }^{14}$ Wyrok WSA w Poznaniu z 9 XII 2010 r., sygn. I SA/Po 799/10, www.orzeczenia. nsa.gov.pl (dostęp: 3 II 2016).

${ }^{15}$ Tak wyrok WSA w Warszawie z 26 III 2015 r., sygn. III SA/Wa 2235/14, http:// orzeczenia.nsa.gov.pl (dostęp: 12 VIII 2015).

${ }^{16}$ Por. wyrok WSA w Gdańsku z 27 IV 2011 r., sygn. I SA/Gd 1323/10, http:// orzeczenia.nsa.gov.pl (dostęp: 12 VIII 2015). 
Z pewnościa, jak wskazano powyżej, w sprawie dotyczącej wydania interpretacji indywidualnej na podstawie przepisów prawa podatkowego nie prowadzi się postępowania dowodowego, jednak nie zwalnia to organu podatkowego od dokonania oceny stanu faktycznego przedstawionego przez wnioskodawcę. Także wojewódzkie sądy administracyjne nie mogą uchylać się w tym zakresie od oceny legalności działań organu podatkowego. Dlatego też NSA, rozpoznając merytorycznie skargę, musi brać pod uwagę przesłankę wynikającą z treści art. 188 p.p.s.a.

Jak słusznie zauważa się w literaturze, "W procesie stosowania prawa wykładnia ma na celu ustalenie, jaka norma, a więc o jakiej treści, właściwa jest dla rozstrzygnięcia określonej sprawy, w szczególności zaś wyjaśnienie jej znaczenia w stopniu dostatecznie sprecyzowanym na potrzeby tego rozstrzygnięcia. Wyjaśnienie znaczenia przepisu prawnego, z którego można odkodować normę prawną, sprowadza się, w najszerszym ujęciu, do określenia, do jakich sytuacji, podmiotów czy obiektów dana norma lub jej fragment się odnosi. Jest to wykładnia operatywna realizowana przez podmiot stosujący prawo. W przypadku gdy rozstrzygana jest konkretna sprawa podatkowa, podmiot stosujący prawo, dokonując wykładni operatywnej, musi także ustalić stan rzeczywisty, tak aby można było stwierdzić, czy i w jakim stopniu stan rzeczywisty odpowiada ustawowemu stanowi faktycznemu. Ustalenie tego stanu jest również istotne z punktu widzenia samego zakresu wykładni operatywnej. W wykładni operatywnej chodzi bowiem o ustalenie normy prawnej jedynie $\mathrm{w}$ takim zakresie, jaki jest niezbędny dla rozstrzygnięcia sprawy podatkowej"17. Ustalenie treści normy prawnej nie może mieć jednak cech dowolności. Co ważne, „w interpretacji prawo nie zostaje zastosowane, ale podana zostaje informacja o możliwości takiego zastosowania. Dokonana zostaje subsumpcja, choć tylko w obszarze potencjalności"18. Wprawdzie w wykładni operatywnej „zmienia się perspektywa widzenia poszczególnych właściwości - niejednokrotnie ich układ, przebieg czy rezultaty - tym samym prowadząc do ich odmiennego oglądu niż ten osiągany w ramach innych rodzajów wykładni ${ }^{19}$, to jednak jednym z istotnych warunków realizacji pewności

${ }^{17}$ R. Mastalski, Prawo podatkowe, Warszawa 2011, s. 126.

${ }^{18}$ H. Filipczyk, Postulat pewności prawa w wykładni operatywnej prawa podatkowego, Warszawa 2013, s. 18.

${ }^{19}$ L. Leszczyński, Wykładnia operatywna (podstawowe właściwości), referat wygłoszony na posiedzeniu Komitetu Nauk Prawnych w dniu 26 II 2009 r., „Państwo i Prawo” 2009, nr 9, s. 11 i n. 
prawa jest w przypadku wykładni operatywnej wszechstronne uzasadnienie rekonstrukcji normy prawnej ${ }^{20}$.

Pewność prawa to, zdaniem H. Filipczyk, "cecha prawa polegająca na tym, że podmiot, do którego prawo się odnosi (adresat normy, np. podatnik), jest $w$ stanie przewidzieć determinowane nim skutki faktów (stanów rzeczy), w tym czynów (działań i zaniechań) własnych i innych podmiotów. Pewność prawa należy do jego wartości formalnych, względnych i instrumentalnych. Pewność w obszarze prawa podatkowego odznacza się szczególną doniosłością ze względu na charakterystykę tej gałęzi prawa: ingerencyjnego, skomplikowanego i zmiennego oraz posługującego się techniką samoobliczenia. Nakaz stosowania prawa, w tym dokonywania jego wykładni operatywnej, w sposób urzeczywistniający pewność prawa ma uzasadnienie analityczne, etyczne, tetyczne i utylitarne ${ }^{\prime 21}$.

Dlatego też przyjęcie a priori przez NSA, że art. 83 ust. 1 pkt 11 ustawy o VAT dotyczy wyłącznie usług bezpośrednio związanych z ochroną środowiska morskiego bez poparcia tej tezy analizą przepisów jest niewłaściwe.

Należy przypomnieć, że stawkę $0 \%$ podatku VAT stosuje się m.in. do „usług ratownictwa morskiego, nadzoru nad bezpieczeństwem żeglugi morskiej i śródlądowej oraz usług związanych z ochroną środowiska morskiego i utrzymaniem akwenów portowych i torów podejściowych". NSA, dokonując wykładni tego przepisu, stwierdził, że odnosi się on wyłącznie do takich usług, których celem zasadniczym jest cel związany ze środowiskiem morskim, tzn. że przepis nie obejmuje usług, które mogą zostać osiągnięte jedynie pobocznie, przy realizacji innego celu niezwiązanego bezpośrednio z tym środowiskiem.

W rozpatrywanej sprawie podstawowym zadaniem organów podatkowych było ustalenie znaczenia treści normy prawnej zawartej w przepisie art. 83 ust. 1 pkt 11 ustawy o VAT. Dlatego też należało ustalić zakres pojęcia "ochrona środowiska morskiego", i to nie na podstawie definicji słownikowej, ale opierając się na wszechstronnej analizie przepisów prawa krajowego, unijnego, a nawet międzynarodowego. Brak definicji legalnej nie zwalniał NSA od obowiązku dokonania jej wykładni, zwłaszcza w sytuacji, kiedy rozpoznawał skargę na podstawie art. 188 p.p.s.a.

\footnotetext{
${ }^{20}$ E. Fojcik-Mastalska, R. Mastalski, Prawo finansowe, Warszawa 2013, s. 195.

${ }^{21}$ H. Filipczyk, op. cit., s. 61.
} 
Skoncentrowanie rozważań NSA na pojęciu "związku” w oderwaniu od "ochrony środowiska morskiego" i dokonywanie wiążących rozstrzygnięć w zakresie, czy ów związek ma charakter pośredni czy bezpośredni, jest sprzeczne z ideą wykładni, która nie jest rozumiana jako operacja myślowa ograniczająca się do wykładni jednego przepisu (zwłaszcza wyłącznie wykładni językowej). Wykładnia jest operacja, w toku której dokonuje się przekładu zbioru przepisów ogłoszonych w aktach prawodawczych na zbiór norm postępowania równoznaczny jako całość z danym zbiorem przepisów ${ }^{22}$. Należy podkreślić, że określenie "związek” oznacza "stosunek pomiędzy rzeczami, zjawiskami powiązanymi ze sobą w jakiś sposób" ${ }^{23}$. Nie jest zatem możliwa ocena, czy pomiędzy rzeczami, zjawiskami zachodzi związek pośredni czy bezpośredni, bez ustalenia istoty tych rzeczy bądź zjawisk. Co więcej, NSA w swoich wcześniejszych orzeczeniach zwracał uwagę na rozumienie pojęcia "związek" na gruncie Słownika języka polskiego i stwierdzał, że pojęcie to w języku potocznym ma charakter bardzo szeroki, pozwalający przyjąć, iż "związek może być zarówno bezpośredni, jak i pośredni"24. Do podobnych wniosków NSA doszedł także na gruncie ustawy o podatku dochodowym od osób fizycznych ${ }^{25}$, uznając, że „skoro ustawodawca w art. 21 ust. 1 pkt 28 u.p.d.o.f. używa określenia «W związku z tą sprzedażą» i nie definiuje, co należy rozumieć przez pojęcie związku, to niewątpliwie chodzi mu o językowe, potoczne rozumienie tego pojęcia. Oznaczać to będzie, że chodzi o każdy związek [podkr. E.K. i A.T.], w następstwie którego grunty tracą swój charakter rolny lub leśny, byle tylko można było go powiązać [podkr. E.K. i A.T.] ze sprzedażą ${ }^{\prime 26}$.

Nie ulega wątpliwości, że termin "środowisko” jest jednym z fundamentalnych w obszarze prawa ochrony środowiska ${ }^{27}$. Ustawa p.o.ś.

${ }^{22}$ M. Zieliński, Interpretacja jako proces dekodowania tekstu prawnego, Poznań 1972, s. 26 i n.; idem, Wykładnia prawa. Zasady. Reguty. Wskazówki, Warszawa 2012, s. 47 i n.; Z. Ziembiński, Logika praktyczna, Warszawa 2002, s. 230.

${ }^{23}$ Hasło "Związek", Stownik języka polskiego PWN, http://sjp.pwn.pl/szukaj/ zwi\%C4\%85zek.html (dostęp: 10 IX 2015).

${ }^{24}$ Np. wyrok NSA z 26 IX 2011 r., sygn. II FSK 550/10, http://orzeczenia.nsa.gov.pl (dostęp: 12 VIII 2015).

${ }^{25}$ Ustawa z dnia 26 VII 1991 r. o podatku dochodowym od osób fizycznych (tekst jedn. Dz.U. 2012, poz. 361 ze zm.), dalej „u.p.d.o.f.".

${ }^{26}$ Wyrok NSA z 22 VII 2008 r., sygn. II FSK 732/07, http://orzeczenia.nsa.gov.pl (dostęp: 10 IX 2015).

${ }^{27}$ B. Wierzbowski, B. Rakoczy, Prawo ochrony środowiska. Zagadnienia podstawowe, Warszawa 2012, s. 15. 
zawiera definicję legalną środowiska, która na gruncie tej gałęzi prawa ma znaczenie priorytetowe. Środowisko, w myśl art. 3 pkt 39 p.o.ś., to ogół elementów przyrodniczych, w tym także przekształconych w wyniku działalności człowieka, które w szczególności obejmują powierzchnię ziemi, kopaliny, wody, powietrze, krajobraz, klimat oraz pozostałe elementy różnorodności biologicznej, a także wzajemne oddziaływania pomiędzy tymi elementami. Nie jest to z pewnością definicja wyczerpująca, stała i uwzględniająca wzajemne oddziaływanie różnych elementów przyrodniczych zarówno organicznych, jak i nieorganicznych. Wzajemne oddziaływanie pomiędzy składnikami środowiska ma charakter normatywny, co przekłada się na zakres i formy oraz środki jego ochrony, szczególnie na gruncie prawa krajowego. W literaturze przyjmuje się, że środowisko powinno być ujmowane jako system elementów przyrodniczych obejmujący związki i oddziaływania pomiędzy tymi elementami ${ }^{28}$. Nie bez powodu ustawodawca odwołuje się do oddziaływania elementów przyrodniczych w Ustawie z dnia 3 października 2008 r. o udostępnianiu informacji o środowisku i jego ochronie, udziale społeczeństwa w ochronie środowiska oraz o ocenach oddziaływania

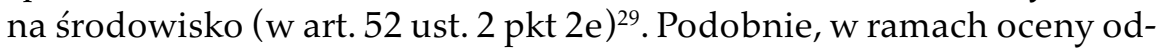
działywania przedsięwzięcia na środowisko „określa się, analizuje oraz ocenia wzajemne oddziaływanie elementów przyrodniczych", o których mowa w art. 61 ust. 2 tejże ustawy ${ }^{30}$. Tymczasem z uzasadnienia wyroku NSA nie wynika, by sąd dokonywał w tym zakresie jakichkolwiek ustaleń, ograniczając się do stwierdzenia, że akty prawne, na które powołał się sąd I instancji, nie definiują pojęcia "środowiska morskiego" oraz że wykładnia dokonana przez WSA w Warszawie jest błędna. Nie jest jasne, skąd pewność składu orzekającego, iż brzeg morski nie stanowi elementu "środowiska morskiego". Poddanie ochrony brzegu morskiego odrębnej regulacji prawnej (ustawa o programie ochrony brzegów) nie wyklucza szerokiego rozumienia terminu "środowisko morskie”. Tym bardziej że ewidentność oddziaływania lądu i morza mieści się we wcześniej przywołanej definicji środowiska.

Kolejną nieprawidłowością zauważalną w uzasadnieniu wyroku jest brak odniesienia do terminu "ochrona środowiska morskiego" w sytuacji,

${ }^{28}$ A. Wasilewski, Uwagi o projekcie ustawy o ochronie środowiska z dnia 17 września 1999 r., „Przegląd Legislacyjny" 2000, nr 1, s. 66.

${ }^{29}$ Tekst jedn. Dz.U. 2013, poz. 1235 ze zm.

${ }^{30}$ Por. W. Radecki, Ochrona walorów turystycznych w prawie polskim, Warszawa 2011, s. 157. 
gdy ustawodawca określa znaczenie ochrony środowiska, które bez wątpienia dotyczy także ochrony środowiska wodnego (morskiego). Rozważania na temat związku pośredniego, „ewentualnego", mają charakter wtórny wobec tych ustaleń.

Ochrona środowiska w prawie polskim określona została w szczególności jako: 1. racjonalne kształtowanie środowiska i gospodarowanie zasobami przyrodniczymi zgodnie z zasadą zrównoważonego rozwoju; 2. przeciwdziałanie lub zapobieganie szkodliwym wpływom na środowisko powodującym jego zniszczenie, zanieczyszczenie, zmiany cech fizycznych lub charakteru elementów przyrodniczych; 3. przywracanie do stanu właściwego elementów przyrodniczych (art. 3 pkt 13 p.o.ś). W piśmiennictwie uważa się, że ochrona środowiska powinna uwzględniać aspekt konserwacyjny, aspekt restytucyjny oraz aspekt prewencyjny ${ }^{31}$.

Aspekt restytucyjny umożliwia przywracanie środowiska do stanu poprzedniego bądź stanu właściwego lub zgodnego z prawem. I niekoniecznie musi mieć związek z działalnością człowieka. Nie można też wykluczyć, czego dowodem są liczne badania naukowe, wpływu człowieka na podnoszenie poziomu mórz, a tym samym pogłębianie się erozji brzegów. Na marginesie należy dodać, że $z$ aspektem tym wiąże się niewątpliwie kompensacja przyrodnicza, przez którą rozumie się „zespół działań [...] prowadzących do przywrócenia równowagi przyrodniczej na danym terenie, wyrównania szkód dokonanych w środowisku przez realizację przedsięwzięcia i zachowania walorów krajobrazowych"32.

Idąc dalej, należy stwierdzić, że podstawowe zagadnienia dotyczące ochrony wód zostały zawarte w ustawie p.o.ś., która wprost odsyła do Ustawy z dnia 18 lipca 2001 r. Prawo wodne ${ }^{33}$. Przy czym ustawa Prawo wodne dotyczy generalnie ochrony wód, w tym wód morskich. Bezsprzeczne jest, że podstawowym podziałem wód jest podział na wody morskie i wody śródlądowe. Ustawa Prawo wodne określa cele środowiskowe odrębnie dla wód morskich i rozumie przez nie: a) pożądany stan podstawowych cech i właściwości wód morskich, w tym dna i skały macierzystej znajdujących się na obszarze morza terytorialnego, wyłącznej strefy ekonomicznej Rzeczypospolitej Polskiej i wód przybrzeżnych, b) presje i oddziaływania na wody morskie, w tym na

\footnotetext{
${ }^{31}$ B. Wierzbowski, B. Rakoczy, op. cit., s. 12-13.

${ }^{32}$ Ibidem, s. 12.

${ }^{33}$ Tekst jedn. Dz.U. 2015, poz. 469 ze zm.
} 
dno i skałę macierzystą znajdujące się na obszarze morza terytorialnego, wyłącznej strefy ekonomicznej Rzeczypospolitej Polskiej i wód przybrzeżnych - określone jakościowo lub ilościowo (art. 9 pkt 1 aa). W ramach ochrony wód ustawa Prawo wodne, co należy podkreślić, reguluje także utrzymywanie brzegu morskiego. W myśl art. 23 Prawa wodnego „utrzymywanie brzegu morskiego polega na budowie, utrzymywaniu i ochronie umocnień brzegowych w obrębie pasa technicznego ustanowionego przepisami Ustawy z dnia 21 marca 1991 r. o obszarach morskich Rzeczypospolitej Polskiej i administracji morskiej"34. Trzeba zgodzić się ze stanowiskiem, że „do czynności realizowanych najczęściej w ramach utrzymania wód zaliczyć należy m.in.: zabudowę obrywających się brzegów, konserwację lub remont istniejących budowli regulacyjnych" 35 .

Należy także zwrócić uwagę, że przymiotnik „morski” wprawdzie może skłaniać do zastosowania wyłącznie interpretacji językowej, jak ma to miejsce w przywołanych interpretacjach, to jednak w sytuacji, kiedy przepisy prawa polskiego, unijnego ${ }^{36} \mathrm{i}$ międzynarodowego nakazują rozumieć to pojęcie szerzej aniżeli jako dotyczące "morza”, to wykładnia nie może ograniczać się jedynie do „objaśnień słownikowych”. Również działania polskich organów administracji wykazuja, że ochronę środowiska morskiego należy rozumieć szerzej, niż to wynika z wykładni językowej, np. w jednym z najnowszych opracowań Studium Uwarunkowań zagospodarowania przestrzennego Polskich Obszarów Morskich "Polski Obszar Morski" obejmuje nie tylko morze, ale także jego brzeg ${ }^{37}$. Co więcej, na taki właśnie kierunek wykładni wskazywały Najwyższa Izba Kontroli i Krajowa Izba Odwoławcza oraz Urzędy Morskie.

Można odnieść wrażenie, że $\mathrm{w}$ analizowanej sprawie zachodzi naruszenie art. $14 \mathrm{~b} \S 1 \mathrm{w}$ zw. $\mathrm{z}$ art. $14 \mathrm{a} \S 2$ oraz art. $121 \S 1$ Ustawy z dnia 29 sierpnia 1997 r. Ordynacja podatkowa ${ }^{38}$ przez zawężająca, naruszającą zasadę in dubio pro tributario interpretację przepisów.

\footnotetext{
${ }^{34}$ Tekst jedn. Dz.U. 2013, poz. 934 ze zm.

${ }^{35}$ I. Koza i in., w: Nowe prawo wodne, pod red. I. Kozy, Zielona Góra 2002, s. 22.

${ }^{36}$ Faktem jest, że Dyrektywa 2008/56/WE w preambule zawężająco określa zakres przedmiotowy, jednak analizując jej treść, nie sposób nie zauważyć, iż jej postanowieniami objęto także ekosystemy morskie i przybrzeżne jako pewien system obszaru morskiego, którego celem jest zachowanie morskiej różnorodności biologicznej.

${ }^{37}$ Tak Studium Uwarunkowań zagospodarowania przestrzennego Polskich Obszarów Morskich, http://www.ums.gov.pl/ObszaryMorskie/2014/INZ_Studium_prezentacja-_listopad2014.pdf (dostęp: 12 VIII 2015).

38 Tekst jedn. Dz.U. 2015, poz. 613 ze zm.
} 
Sąd Najwyższy w wyroku z 22 października 1992 r., sygn. III ARN $50 / 92^{39}$, wskazał, że fundamentalną zasadą prawa podatkowego $\mathrm{w}$ demokratycznym państwie prawnym jest to, iż "zakres przedmiotu opodatkowania musi być precyzyjnie określony w ustawie podatkowej, a interpretacja jej przepisów nie może być rozszerzająca". Wobec tego „postanowienia wszelkich aktów prawnych nie mogą być uzupełniane, rozszerzane bądź modyfikowane w drodze wykładni" ${ }^{\prime 4}$. Interpretacja nie może być również zawężająca. Minister finansów w interpretacji ogólnej stwierdził bowiem, że jeśli organ podatkowy natrafi na wątpliwości co do znaczenia przepisu w konkretnej sytuacji faktycznej, a wątpliwości tych nie będzie można usunąć w trakcie prawidłowo prowadzonej wykładni przepisów prawa podatkowego, to wówczas, stosując art. 2a Ordynacji podatkowej, powinien przyjąć znaczenie przepisów korzystniejsze dla podatnika. W przypadku podatków zharmonizowanych w procesie wykładni przepisów prawa podatkowego nie można pominąć wykładni prounijnej ${ }^{41}$.

Glosatorom nie chodzi o dokonywanie analizy prawnej zasady interpretowania wszelkich wątpliwości wynikających z niejasności przepisów prawa podatkowego na korzyść podatnika, lecz o zwrócenie uwagi na budzący wątpliwości sposób rozstrzygania przez NSA. Dlatego też podkreślają, że wyrok NSA jest wiążący jedynie w sprawie o sygn. III SA/Wa 2842/13, a sądy administracyjne orzekające w podobnych sprawach winny samodzielnie dokonywać wykładni art. 83 ust. 1 pkt 11 ustawy o VAT.

${ }^{39}$ Wyrok SN z 22 X 1992 r., sygn. III ARN 50/92, OSNC 1993, nr 10, poz. 18.

${ }^{40}$ A. Mariański, Rozstrzyganie wat pliwości na korzyść podatnika, cz. II, „Przegląd Podatkowy" 2009/10/37-43; idem, Rozstrzyganie wattpliwości na korzyść podatnika. Zasada prawa podatkowego, Warszawa 2011, s. 98 i n.

${ }^{41}$ Interpretacja Ogólna Ministra Finansów z dnia 29 XII 2015 r., nr PK4.8022.44.2015. 